\title{
Perbedaan Kemampuan Komunikasi Matematis Siswa Yang Diajar Dengan Model Pembelajaran Kooperatif Tipe TSTS Dan Yang Diajar Dengan Model Pembelajaran Konvensional Di Kelas VIII SMPN 4 Kendari
}

\author{
(Differences Of Teacher's Mathematical Communication Ability Used By Tsts And \\ Teached Cooperative Learning Model With Conventional Learning Model In Class VIII \\ SMPN Kendari)
}

\author{
Rahmawati $^{1}$, La Masi ${ }^{2}$, Kadir $^{3}$, Jafar $^{3}$ \\ ${ }^{1}$ Alumnus Jurusan Pendidikan Matematika FKIP Universitas Halu Oleo \\ ${ }^{2}$ Dosen Pendidikan Matematika FKIP Universitas Halu Oleo; Co-author: lamasimbahido1966@yahoo.co.id \\ ${ }^{3}$ Dosen Pendidikan Matematika FKIP dan PPs Universitas Halu Oleo
}

\begin{abstract}
Abstrak: Tujuan penelitian ini adalah mengujiperbedaan kemampuan komunikasi matematis siswa yang diajar dengan model pembelajaran kooperatif tipe TSTS dan yang diajar dengan model pembelajaran konvensional. Penelitian ini adalah penelitian quasi eksperimenkelas VIII SMP Negeri 4 Kendari pada bulan April-Mei 2018. Populasi penelitian ini adalah seluruh siswa kelas VIII di SMP Negeri 4 Kendari yang diajar oleh guru yang sama dan terdaftar pada tahun ajaran 2017/2018 yang tersebar pada empat kelas paralel, yaitu kelas VIII8 sampai VIII11. Teknik pengambilan sampel pada penelitian ini dilakukan secara purposive sampling. Teknik pengumpulan data dilakukan dengan pemberian instrumen penelitian berupa lembar observasi dan tes kemampuan komunikasi matematis siswa yang berbentuk tes uraian. Teknik analisis data menggunakan statistik deskriptif dan statistik inferensial dengan uji-t satu pihak pada $\alpha=0,05$. Hasil penelitian ini adalah kemampuan komunikasi matematis siswa yang diajar dengan model pembelajaran kooperatif TSTS lebih tinggi dari kemampuan komunikasi matematis siswa yang diajar dengan model pembelajaran konvensional.
\end{abstract}

Kata kunci: Model Pembelajaran Kooperatif Tipe TSTS, Kemampuan Komunikasi Matematis

\begin{abstract}
TSTS and taught with conventional learning models. This study was astudy quasi-experimentalof VIII grade 4 State Junior High School 4 in April-May 2018. The population of this study was all eighth grade students in SMP Negeri 4 Kendari who were taught by the same teacher and registered in the 2017/2018 school year spread over four parallel class, namely classes VIII8 to VIII11. The sampling technique in this study was conducted by purposive sampling. Data collection techniques were carried out by giving research instruments in the form of observation sheets and tests of students' mathematical communication skills in the form of a description test. Data analysis techniques used descriptive statistics and inferential statistics with one-party t-test at $\alpha=0.05$. The results of this studyadalaah kmathematical communicationCapacity of students taught by cooperative learning model TSTS higher than mathematically communication skills of students taught by conventional learning models..
\end{abstract}

Keywords: Cooperative Learning Model Type TSTS, Mathematical Communication Ability.

\section{PENDAHULUAN}

Pembelajaran merupakan suatu sistem, yang terdiri atas berbagai komponen yang saling menghubungkan satu dan yang lain. Komponen tersebut meliputi: tujuan, materi, metode, dan evaluasi. Keempat komponen pembelajaran tersebut harus diperhatikan oleh guru dalam memilih dan menentukan

model-model pembelajaran yang akan digunakan dalam kegiatan pembelajaran (Rusman, 2010: 1). Sehingga pembelajaran akan berjalan dengan efektif sesuai dengan komponen pembelajaran. Hakikatnya pengetahuan matematika. Menurut 
Suherman (2003: 57), dalam pembelajaran matematika, para siswa dibiasakan untuk memperoleh pemahaman melalui pengalaman tentang sifat-sifat yang dimiliki dan yang tidak dimiliki dari sekumpulan objek (abstraksi). Abstraksi merupakan sebuah proses yang ditempuh pikiran untuk sampai pada konsep yang bersifat umum. Selanjutnya, dengan abstraksi tersebut para siswa dilatih untuk membuat perkiraan, terkaan atau kecenderungan berdasarkan kepada pengalaman atau pengetahuan yang dikembangkan melalui contoh-contoh khusus yang disebut dengan generalisasi.

Komunikasi matematis berperan dalam membantu siswa memahami matematika maupun mengungkapkan keberhasilan belajar siswa. Hal ini sesuai dengan NCTM (1989: 214), matematika sebagai alat komunikasi dapat: 1) mengungkapkan dan menjelaskan pemikiran mereka tentang ide matematika dan hubungannya; 2) merumuskan definisi matematika dan membuat generalisasi yang diperoleh melalui investigasi; 3) mengungkapakan ide matematika secara lisan dan tulisan; 4) menyajikan matematika yang dibaca dan ditulis dengan pengertian; 5) menjelaskan dan mengajukan pertanyaan yang berhubungan dengan matematika yang biasa dibaca dan didengar; dan 6) menghargai nilai ekonomis daya dan keindahan matematika.

Beberapa penjelasan tersebut dapat disimpulkan bahwa komunikasi dalam matematika (Communicating in Mathematic) terdiri dari 1) komunikasi lisan (Talking) seperti membaca (Reading), 2) Mendengar (Listening), 3) Diskusi (Discussing), 4) menjelaskan (Explaining), 5) Sharing dan 6) komunikasi tulisan atau menulis (Writing) melalui pengungkapan ide matematika dalam fenomena dunia nyata melalui grafik, tabel, persamaan aljabar, ataupun dalam bahasa sehari-hari (written word). Pada penelitian ini, penulis terfokus pada aspek: (1) Menjelaskan ide, situasi dan relasi matematika secara tulisan dan menyusun argumen atau mengungkapkan pendapat serta memberikan penjelasan atas jawaban; (2) Menyatakan situasi atau ide-ide matematika dalambantuk gambar, diagram atau grafik; dan (3) Menyatakan situasi, gambar, diagram atau benda nyata ke dalam bahasa, simbol, ide atau model matematika.

Eggen danKauchak dalam Novita (2014: 131), pembelajaran kooperatif merupakan suatu kumpulan strategi mengajaryang digunakan guru untuk menciptakan kondisi belajar sesama siswa. Siswa yang satu membantu siswa lainnya dalam mempelajari sesuatu. Dengan kata lain, pembelajaran kooperatif dapat didefinisikan sebagai salah satu model pembelajaran dimana aktifitas pembelajaran dilakukan guru dengan menciptakan kondisi belajar yang memungkinkan terjadinya proses belajar sesama siswa.

Teknik belajar mengajar Dua Tinggal Dua Tamu (Two Stay Two Stray) dikembangkan oleh Spencer Kagan (1992). Teknk ini digunakan dalam semua mata pelajaran dan untuk semua tingkat usia anak didik. Struktur Dua Tinggal Dua Tamu dapat memberikan kesempatan kepada siswa untuk membagikan informasi dengan kelompok lain (Lie, 2012). Model pembelajaran kooperatif Dua Tinggal Dua Tamu adalah dua orang siswa tinggal di kelompok dan dua orang siswa bertamu ke kelompok lain. Dua orang yang tinggal bertugas memberikan informasi kepada tamu tentang hasil kelompoknya, sedangkan yang bertamu bertugas mencatat hasil diskusi kelompok yang dikunjunginya (Shoimin, 2014: 222). Sehingga akan terjadi komunikasi dan menghasilkan satu kesimpulan yang disepakati dari hasil diskusi tersebut.

Langkah-langkah yang harus guru lakukan dalam menerapkan teknik TSTSsebagai berikut:

1. Siswa bekerja sama dalam kelompok berempat seperti biasa. 
2. Setelah selesai, dua orang dari masingmasing kelompok akan meninggalkan kelompoknya dan masing-masing bertamu ke dua kelompok yang lain untuk saling berkomunikasi.

3. Dua orang yang tinggal dalam kelompok bertugas membagikan hasil kerja dan informasi mereka ke tamu mereka.

\section{METODE PENELITIAN}

Jenis penelitian ini adalah quasi eksperimen. Penelitian ini bertujuan untuk mengetahui perbedaan kemampuan komunikasi matematis siswa antara yang diajar dengan model pembelajaran kooperatif tipe two stay two stray (TSTS) dan yang diajar dengan model pembelajaran konvensional. Penelitian dilaksanakan di SMP Negeri 4 Kendari. Waktu pelaksanaannya pada bulan April semester genap Tahun Ajaran 2017/2018.

Populasi dalam penelitian ini adalah seluruh siswa kelas VIII di SMP Negeri 4 Kendari yang diajar oleh guru yang sama yang terdaftar pada tahun ajaran 2017/2018 yang tersebar pada empat kelas paralel, yaitu kelas $\mathrm{VIII}_{8}$ sampai $\mathrm{VIII}_{11}$.Pengambilan sampel pada penelitian ini dilakukan secara purposive sampling, yaitu kelas $\mathrm{VIII}_{8}$ dan kelas $\mathrm{VIII}_{11}$. Adapun penentuan kelas yang akan digunakan sebagai kelas eksperimen dan kelas kontrol akan dilakukan secara random yang diperoleh kelas $\mathrm{VIII}_{8}$ sebagai kelas kontrol dan kelas $\mathrm{VIII}_{11}$ sebagai kelas eksperimen yang kemudian diajar menggunakan model pembelajaranTSTS.

Desain penelitian yang digunakan adalah model Posttest Only Control Group Design. Adapun desainnya sebagai berikut.

$\begin{array}{lcc}\text { Kelas } & \text { Perlakuan } & \text { Posttest } \\ \text { Eksperimen } & \mathrm{X} & \mathrm{Y}_{1} \\ \text { Kontrol } & - & \mathrm{Y}_{2}\end{array}$

(Setyosari, 2013: 187).
4. Tamu mohon undur diri dan kembali ke kelompok mereka sendiri dan melaporkan temuan mereka dari kelompok lain. Kelompok mencocokkan dan membahas hasil kerja mereka. (Aqib, 2013: 35).

Keterangan:

$\mathrm{X}=$ Pembelajaran matematika dengan model pembelajaran kooperatif tipe TSTS

$\mathrm{Y}_{1}=$ Hasil Posttestsiswa pada kelas eksperimen yang diajar dengan model pembelajaran kooperatif tipe TSTS

$\mathrm{Y}_{2}=$ Hasil Posttestsiswa pada kelas kontrol yang diajar dengan pembelajaran konvensional

Penelitian ini mempunyai dua instrumen, yaitu instrumen berupa lembar observasi kegiatan guru dan aktivitas siswa dan instrumen tes kemampuan komunikasi matematis siswa.

Instrumen Tes kemampuan komunikasi matematis dalam penelitian ini berupa tes tertulis dalam bentuk uraian (essay). Instrumen dalam penelitian ini disusun berdasarkan tiga jenis masalah komunikasi matematis, yaitu: (1) Menjelaskan ide, situasi dan relasi matematika secara tulisan dan menyusun argumen atau mengungkapkan pendapat serta memberikan penjelasan atas jawaban; (2) Menyatakan situasi atau ideide matematika dalam bantuk gambar, diagram atau grafik; dan (3) Menyatakan situasi, gambar, diagram atau benda nyata ke dalam bahasa, simbol, ide atau model matematika.

Penilaian untuk setiap butir soal tes kemampuan komunikasi matematis digunakanpedomanpemberianskor yang disajikanpada tabel 1 . 
Tabel 1. Pedoman Penskoran Butir Soal Tes Kemampuan Komunikasi

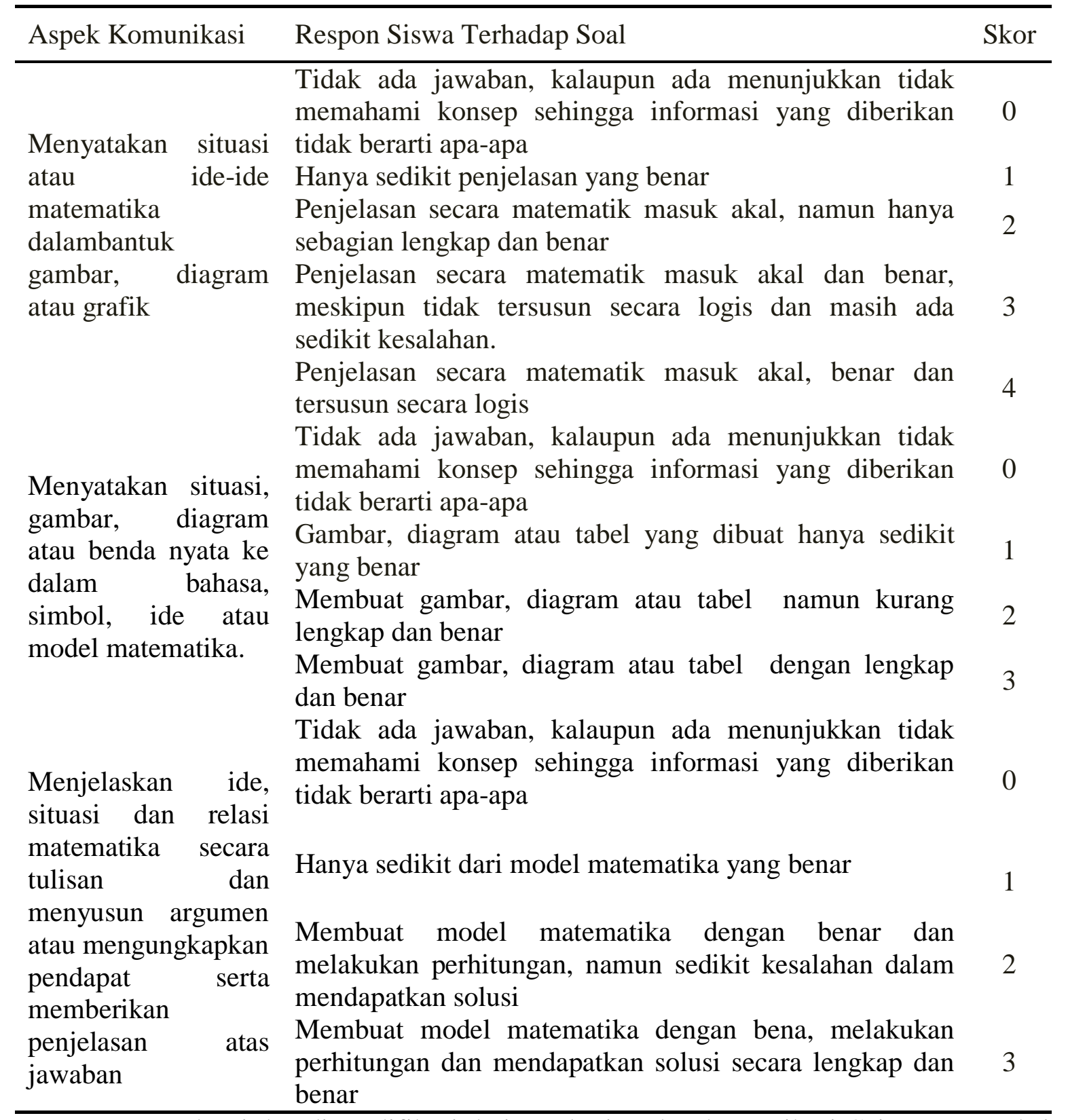

Keterangan: adopsi dan di modifikasi dari pemberian skor komunikasi Cai, Lane Jacobsin dalam Zulkarnaen ( 2010: 34.

Analisis data dalam penelitian ini menggunakan analisis deskriptif dan analisis inferensial. Analisis deskriptif digunakan untuk mendeskriptifkan karakteristik data masing-masing kelompok dan analisis inferensial digunakan untuk menguji hipotesis dengan statistik uji-t.Analisis deskriptif digunakan untuk memperoleh data tentang aktivitas/ partisipasi guru dan siswa dalam pembelajaran. Analisis deskriptif juga dimaksudkan untuk mendeskripsikan kemampuan komunikasi matematis siswa melalui skor rata-rata yang diperoleh siswa baik pada kelas kontrol maupun kelas eksperimen. Analisis deskriptif yang digunakan berupa perolehan nilai rata-rata $(\bar{x})$, median $(M e)$, modus $(M o)$, varians, standar deviasi, nilai maksimum $\left(x_{\max }\right)$, dan nilai minimum $\left(x_{\min }\right)$.

Kemudian untuk menentukan kategori tingkat kemampuan komunikasi 
matematik siswa, nilai hasil tes kemampuan komunikasi matematik siswa dikonversi ke bentuk kualitatif dengan mempertimbangkan pedoman penilaian
(Departemen Pendidikan Nasional, 2006 dalam Septian, 2004: 31).

Tabel 2. Kategori Kemampuan Komunikasi Matematis

\begin{tabular}{cc}
\hline Interval & Kategori \\
\hline $80<x \leq 100$ & Sangat Baik \\
$60<x \leq 80$ & Baik \\
$40<x \leq 60$ & Cukup \\
$20<x \leq 40$ & Kurang \\
$0<x \leq 20$ & Sangat Kurang \\
\hline
\end{tabular}

Analisis inferensial dimaksudkan untuk menguji hipotesis penelitian, namun terlebih dahulu melalui tahapan yang lain, yaitu uji normalitas dan uji homogenitas sebagai prasyarat untuk pengujian hipotesis dan uji hipotesis.Uji normalitas data dimaksudkan untuk mengetahui apakah data yang diperoleh berasal dari populasi yang berdistribusi normal atau tidak. Untuk keperluan ini maka statistik yang digunakan adalah uji KolmogorovSmirnov. Dalam penelitian ini uji Kolmogorov-Smirnov dilakukan dengan menggunakan program IBM SPSS dengan kriteria pengambilan keputusan sebagai berikut:

a) Jika nilai Asymp. Sig (2-tailed) $\geq \alpha$ pada $\alpha 0,05$ maka data berasal dari populasi yang berdistribusi normal.

b) Jika nilai Asymp. Sig (2-tailed) $<\alpha$ pada $\alpha 0,05$ maka data berasal dari populasi yang tidak berdistribusi normal.

Uji homogenitas data yang dimaksudkan untuk mengetahui apakah varians data kedua kelompok yang diteliti mempunyai varians yang homogen atau tidak. Pengujian homogenitas varians dilakukan dengan uji $\mathrm{F}$ dengan rumus menurut Sundayana (2015: 144) sebagi berikut :

Kriteria uji:

$$
\mathrm{F}_{\text {hitung }}=\frac{\text { varians terbesar }}{\text { varians terkecil }}
$$

Jika $F_{\text {hit }} \leq \mathrm{F}_{\text {tabel }}$ maka varians kedua kelompok homogen.

Jika $\quad F_{\text {hit }}>F_{\text {tabel }}$ maka varians kedua kelompok tidak homogen.

Kriteria uji dengan SPSS: Jika nilai signifikansi $\geq \alpha(0,05)$, maka varians kedua kelompok homogen. Jika nilai signifikansi $<\alpha(0,05)$, maka varians kedua kelompok tidak homogen.

Uji hipotesis dengan t-test untuk mengetahui lebih lanjut kemampuan komunikasi matematis siswa dari pemberian perlakuan model pembelajaran TSTSdan pembelajaran konvensional secara terpisah terhadap kemampuan komunikasi matematis siswa.

Jika ditemukan data terdistribusi normal dan varians homogen, maka pengujian hipotesis yang digunakan adalah statistik uji-t. Rumus t-test sebagai berikut (Sundayana, 2015: 146).

$$
\mathrm{t}_{\text {hitung }}=\frac{\bar{X}_{1}-\bar{X}_{2}}{\mathrm{~S}_{\mathrm{g}} \sqrt{\frac{1}{n_{1}}+\frac{1}{n_{2}}}}
$$

dengan:

$$
S_{g}=\sqrt{\frac{\left(n_{1}-1\right) S_{1}^{2}+\left(n_{2}-1\right) S_{2}^{2}}{n_{1}+n_{2}-2}}
$$

Keterangan:

$\mathrm{t}_{\text {hitung }}=$ Nilai hitung untuk uji-t

$\bar{X}_{1}=$ Rata-rata kelas eksperimen

$\bar{X}_{2}=$ Rata-rata kelas kontrol

$\mathrm{n}_{1}=$ Jumlah siswa kelas eksperimen 
$\mathrm{n}_{\mathrm{z}}=$ Jumlah siswa kelas kontrol

$\mathrm{S}_{\mathrm{g}}=$ Simpangan baku gabungan

$\mathrm{S}_{1}^{2}=$ Varians data kelas eksperimen

$\mathrm{S}_{2}^{2}=$ Varians data kelas kontrol

Kriteria uji dengan SPSS: Jika nilai $\frac{\text { Sig.(2-tailed) }}{2} \geq \alpha=0,05$, maka $\mathrm{H}_{0}$ diterima. Jika nilai $\frac{\text { Sig.(2-tailed })}{2}<\alpha=$ 0,05, maka $\mathrm{H}_{0}$ ditolak. Pengujian hipotesis $: \mathrm{H}_{0}: \mu_{1} \leq \mu_{2}$ lawan $\mathrm{H}_{1}: \mu_{1}>\mu_{2}$

Keterangan :

$\mu_{1}=$ Rata-rata kemampuan komunikasi matematis siswa yang diajar dengan menggunakan model pembelajaran kooperatif tipe TSTS

$\mu_{2}=$ Rata-rata kemampuan komunikasi matematis siswa yangdiajar dengan menggunakan pembelajaran konvensional.

Dalam sebuah penelitian, jika data hasil penelitian diketahui sebaran datanya berdistribusi normal tetapi mempunyai varians yang tidak homogen, maka Uji t' dapat dilakukan dengan rumus sebagai berikut:

$$
t^{\prime}=\frac{\overline{\mathrm{X}_{1}}-\overline{\mathrm{X}_{2}}}{\sqrt{\frac{S_{1}^{2}}{\mathrm{n}_{1}}+\frac{s_{1}^{2}}{\mathrm{n}_{1}}}}
$$

(Sundayana, 2015: 148).

Keterangan:

$\overline{\mathrm{X}}_{1}$ : rata-rata sampel kelas eksperimen

$\overline{\mathrm{X}}_{2}$ : rata-rata sampel kelas kontrol

$\mathrm{n}_{1}$ : jumlah anggota sampel kelas eksperimen

$\mathrm{n}_{2}$ : jumlah anggota sampel kelas kontrol

$\mathrm{s}_{1}{ }^{2}$ : varians sampel kelas eksperimen

$\mathrm{s}_{2}{ }^{2}$ : varians sampel kelas control Dengan $\alpha=0,05$, Keputusan pengujiannya adalah.

1. Jika $t_{\text {hitung }} \leq t_{\text {tabel }}$ maka $H_{0}$ diterima dan $H_{1}$ ditolak.

2. Jika $t_{\text {hitung }}>t_{\text {tabel }}$ maka $H_{1}$ diterima dan $H_{0}$ ditolak.

kooperatif tipeTSTS pada materi bangun ruang sisi datar dapat dilihat pada Tabel 3.

\section{HASIL PENELITIAN}

Hasil observasi terhadap pelaksanaan pembelajaran matematika dengan menggunakan model pembelajaran

Tabel 3. Deskripsi Keberhasilan Pelaksanaan Pembelajaran oleh Guru pada Kelas Eksperimen

\begin{tabular}{ccc}
\hline Pertemuan & Skor Total & Persentase $(\%)$ \\
\hline I & 14 & 70 \\
II & 16 & 80 \\
III & 16 & 80 \\
IV & 17 & 85 \\
V & 18 & 90 \\
\hline
\end{tabular}

Berdasarkan hasil observasi terhadap pelaksanaan pembelajaran matematika dengan menggunakan model pembelajaran kooperatif tipe TSTS yang dilakukan oleh peneliti di kelas eksperimen pada materi bangun ruang sisi datar, keberhasilan pengelolaan pembelajaran pada pertemuan pertama masuk dalam kriteria sedang dengan tingkat keberhasilan sebesar $70 \%$.

Pelaksanaan pembelajaran pada pertemuan kedua dan ketiga sudah mulai membaik dengan tingkat keberhasilan $80 \%$. Pada pertemuan ke empat sudah lebih baik lagi dengan tingkat keberhasilan $85 \%$. Pada pertemuan kelima sudah sangat baik dengan tingkat keberhasilan yang sama yaitu $90 \%$ sudah terlakasana. Dimana, pada kegiatan pendahuluan semua kegitan pembelajaran dapat terlaksana, hanya saja peneliti tidak memberikan penghargaan kepada siswa mengenai pembelajaran TSTS. Sementara, 
pada kegiatan inti peneliti belum juga mempunyai hadiah yang dapat diberikan kepada siswa yang melaksanakan presentasi, dan kegiatan penutup dapat terlaksana dengan baik.

Rata-rata presentase pelaksanaan pembelajaran dengan model pembelajaran kooperatif tipe TSTS dari pertemuan pertama sampai pertemuan kelima yakni 81\%. Kekurangan-kekurangan yang dilakukan guru pada proses pembelajaran di kelas eksperimen, disebabkan karena guru masih berusaha menyesuaikan diri dengan kondisi pembelajaran yang baru dan karakteristik siswa yang beragam. Oleh karena itu, untuk memperbaikinya peneliti lebih menyesuaikan langkahlangkah pembelajaran dengan waktu yang dibutuhkan dan lebih mencoba mengenal dan memahami karakter siswa yang beragam.

Hasil Pengamatan aktivitas siswa pada kelas eksperimen selama pembelajaran dapat dilihat pada Tabel 3 .

Tabel 3. Deskripsi Keaktifan Siswa Selama Pembelajaran Pada Kelas Eksperimen

\begin{tabular}{ccc}
\hline Pertemuan & Skor Total & Persentase (\%) \\
\hline I & 60 & 68,18 \\
II & 67 & 76,18 \\
III & 72 & 81,81 \\
V & 77 & 87,5 \\
VI & 80 & 90,9 \\
\hline
\end{tabular}

Berdasarkan hasil observasi aktivitas siswa dalam pelaksanaan pembelajaran matematika menggunakan model pembelajaran kooperatif tipe TSTS pada materi bangun ruang sisi datar, pada pertemuan pertama ketercapaian seluruh aspek yang diamati adalah 68,18\%. Presentase ini belum dapat dikatakan aktif. Pada pertemuan kedua sudah mulai mengalami peningkatan, yakni 76,18.

Pertemuan ketiga sampai dengan pertemuan kelima memperlihatkan peningkatan ketercapaian aspek yang diamati yakni berturut-turut $81,81 \%$, $87,5 \%$, dan $90,9 \%$. Dimana pada pertemuan ketiga sampai pada pertemuan kelima, siswa sudah mulai terbiasa dengan LKPD dengan teman kelompoknya serta mau saling berkomunikasi untuk menyelesaikan LKPD yang diberikan. Akan tetapi, mereka masih mengalami kesulitan dalam menemukan penyelesaian masalah sendiri dalam LKPD. Sehingga bimbingan dan motivasi dari guru masih sangat diperlukan. Secara keseluruhan rata-rata presentase keaktifan siswa dari pertemuan pertama sampai pertemuan kelima yakni mencapai 80,914 \%, yang berarti siswa sudah tergolong aktif.

Hasil analisis deskriptif pada kelas eksperimen dengan jumlah siswa 35 diperoleh nilai terendah 60,00 dan nilai tertinggi 90 , nilai rata-rata 78,29 , median atau nilai tengah 80,00 , modus atau nilai yang sering muncul 85,00 sementara standar deviasi 7,57 dan varians 57,27. Dan hasil analisis deskriptif pada kelas kontrol dengan jumlah siswa 34 diperoleh nilai terendah 55,00 dan nilai tertinggi 90,00 , nilai rata-rata 73,68 , median atau nilai tengah 75,00 , modus atau nilai yang sering muncul yaitu 75,00, standar deviasi 8,38 , dan varians 70,17. Hal ini menunjukkan bahwa pada kelas eksperimen lebih banyak siswa yang kemampuan komunikasinya di atas ratarata, sedangkat pada kelas kontrol lebih banyak siswa yang kemampuan komunikasinya di bawah rata-rata. Deskripsi kemampuan komunikasi matematis siswa pada kelas eksperimen dan kelas kontrol terlihat jelas kamampuan komunikasi matematis siswa kelas eksperimen lebih baik jika dibandingkan kelas kontrol, baik dilihat dari nilai 
maksimum, minimum, rata-rata, median, modus, standar deviasi dan variansnya.
Adapun distribusi data hasil posttest kemampuan komunikasi matematis siswa dapat dilihat pada tabel 4 .

Tabel 4. Distribusi Frekuensi dan Klasifikasi Kemampuan Komunikasi Matematis Siswa (Posttest)

\begin{tabular}{cccccc}
\hline $\begin{array}{c}\text { Rentang } \\
\text { Nilai }\end{array}$ & Kategori & $\begin{array}{c}\text { Model Pembelajaran Two } \\
\text { Stay Two Stray } \\
\text { Frekuensi } \\
\text { Persentase } \\
(\%)\end{array}$ & $\begin{array}{c}\text { Model Pembelajaran } \\
\text { Konvensional } \\
\text { Prekuensi } \\
\text { Prsentase } \\
(\%)\end{array}$ \\
\hline $80<\mathrm{X} \leq 100$ & Sangat Baik & 12 & 34,28 & 4 & 11,76 \\
$60<\mathrm{X} \leq 80$ & Baik & 22 & 62,86 & 27 & 79,41 \\
$40<\mathrm{X} \leq 60$ & Cukup & 1 & 2,86 & 3 & 8,82 \\
$20<\mathrm{X} \leq 40$ & Kurang & 0 & 0 & 0 & 0 \\
$0<\mathrm{X} \leq 20$ & Sangat & 0 & 0 & 0 & 0 \\
\multicolumn{7}{c}{ Jumlah } & Kurang & 35 & 100 & 34 & 100 \\
\hline
\end{tabular}

Berdasarkan tabel 4 diatas terlihat bahwa siswa yang mendapat rentang nilai antara $0<\mathrm{X} \leq 20$ (sangat kurang) dan rentang nilai antara $20<X \leq 40$ (kurang) untuk kelas eksperimen $0 \%$, begitu pula untuk kelas kontrol yaitu $0 \%$, untuk rentang nilai $40<\mathrm{X} \leq 60$ (cukup) pada siswa kelas eksperimen 2,86 \%, sedangkan pada kelas kontrol $8,82 \%$, untuk rentang nilai $60<\mathrm{X} \leq 80$ (baik) pada kelas eksperimen $62,86 \%$ sedangkan pada kelas kontrol 79,41\%, untuk rentang nilai $80<$ $\mathrm{X} \leq 100$ (sangat baik) pada siswa kelas eksperimen 34,28\% sedangkan pada kelas kontrol $11,76 \%$.

Uji normalitas digunakan untuk mengetahui apakah data kemampuan komunikasi matematis kedua kelas berdistribusi normal atau tidak. Untuk menguji apakah data berdistribusi normal atau tidak digunakan statistik uji normalitas dengan rumus KolmogorovSmirnov, menggunakan program SPSS. Hasil perhitungannya disajikan dalam tabel 5.

Tabel 5. Hasil Analisis Statistik Uji Normalitas Data One-Sample Kolmogorov-Smirnov Test

\begin{tabular}{|c|c|c|}
\hline & Eksperimen & Kontrol \\
\hline Asymp. Sig. (2-tailed) & 0,32 & 0,22 \\
\hline
\end{tabular}

Pengambilan keputusan untuk normalitas data adalah sebagai berikut:

$\mathrm{H}_{0}$ : Data berdistribusi normal

$\mathrm{H}_{1}$ : Data tidak berdistribusi normal, Dengan kriteria pengujian : $\mathrm{H}_{0}$ diterima, jika nilai Asymp.Sig. $>\alpha(0,05)$.

Pada Tabel 5 diatas dapat dilihat bahwa nilai Asymp. Sig. (2-tailed) untuk kelas eksperimen adalah $0,32>\alpha$ (dengan $\alpha=0,05)$, sehingga $\mathrm{H}_{0}$ diterima. Hal ini berarti bahwa data kemampuan komunikasi matematis siswa pada kelas eksperimen berdistribusi normal. Demikian juga untuk kelas kontrol terlihat bahwa nilai Asymp. Sig. (2-tailed) adalah $0,22>\alpha$ (dengan $\alpha=0,05$ ), sehingga $\mathrm{H}_{0}$ diterima. Hal ini berarti bahwa data kemampuan komunikasi matematis siswa pada kelas kontrol juga berdistribusi normal.

Uji homogenitas digunakan untuk mengetahui apakah data mempunyai varians yang sama (homogen) atau tidak. Untuk menguji apakah data mempunyai 
varians yang sama atau tidak digunakan statistik uji Levene dengan menggunakan program IBM SPSS, sehingga memperoleh nilai signifikan statistik uji Levene adalah 0,72 . Nilai signifikan ini lebih besar dari taraf signifikan 0,05 (nilai sig. $(0,72)>\alpha$ dengan $\alpha=0,05)$, maka $\mathrm{H}_{0}$ diterima. Jadi, dapat disimpulkan bahwa kedua kelompok memiliki varians yang sama. Ini berarti data post test kedua kelompok, yaitu yang mendapat model pembelajaran TSTS dan model pembelajaran konvensional memiliki varians yang sama (homogen).

Karena data berdistribusi normal dan variansnya homogen maka untuk uji perbedaan rata-rata kemampuan komunikasi matematis siswa yang diajar dengan model pembelajaran TSTS dan siswa yang diajar dengan model pembelajaran konvensional, yaitu untuk mengetahui apakah rata-rata kemampuan komunikasi matematis siswa yang diajar dengan model pembelajaran TSTS lebih tinggi dari pada siswa yang diajar dengan model pembelajaran konvensional.

Uji perbedaan dua rata-rata dengan bantuan SPSS digunakan uji independent sample $t-$ test, dengan kriteria pengambilan keputusan sebagai berikut:

1) Jika nilai $\frac{1}{2}$ sig.(2-tailed) $\geq \alpha$ pada $\alpha$ 0,05 , maka $\mathrm{H}_{0}$ diterima.

2) Jika nilai $\frac{1}{2}$ sig.(2-tailed $)<\alpha(0,05)$, maka $\mathrm{H}_{0}$ ditolak

Untuk lebih jelasnya hasil pengujian hipotesis data kemampuan komunikasi matematis siswa pada kelas yang diajar dengan menggunakan model pemebelajaran TSTS dan siswa yang diajar dengan menggunakan model pembelajaran konvensional dapat dilihat pada tabel 6 .

Tabel 6. Hasil Analisis Statistik Uji Perbedaan Rata- rata Kemampuan Komunikasi Matematis Siswa Kelas Eksperimen dan Kelas Kontrol

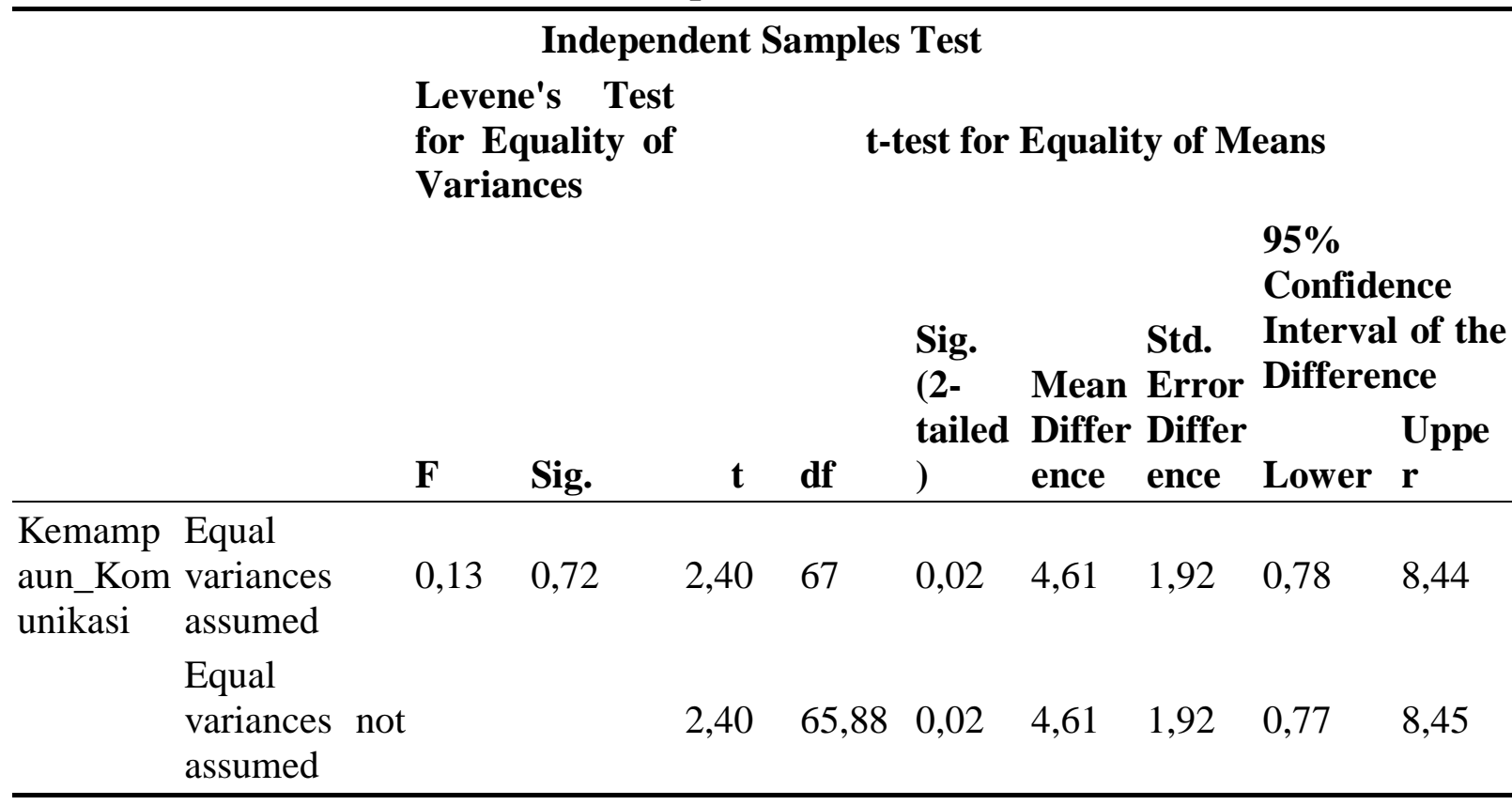

Berdasarkan tabel 6 di atas diperoleh nilai $\frac{1}{2}$ Sig. $(2-$ tailed $)=0,01$, dalam hal ini nilai $\frac{1}{2}$ Sig. $(2-$ tailed $)<0,05$, sehingga keputusannya adalah tolak $\mathrm{H}_{0}$.
Kesimpulannya, rata-rata kemampuan komunikasi matematis siswa yang diajar dengan model TSTS lebih tinggi daripada siswa yang diajar dengan model pembelajaran Konvensional. 


\section{PEMBAHASAN}

Jenis penelitian ini adalah penelitian eksperimen tentang Perbedaan Kemampuan Komunikasi Matematis Siswa yang diajar dengan Model Pembelajaran Kooperatif Tipe TSTS dan yang diajar dengan Model Pembelajan Konvensiaonal di kelas VIII SMP Negeri 4 Kendari. Penelitian ini mulai dilaksanakan pada tanggal 4 April 2018 sampai tanggal 8 Mei 2018. Waktu pembelajaran antara kelas eksperimen dengan kelas kontrol adalah sama, masingmasing 13 jam pelajaran. Kedua kelas diberikan waktu 80 menit pada pertemuan terakhir yang digunakan untuk pelaksanaan Posttest kemampuan komunikasi matematis siswa.

Guru pengajar pada saat pembelajaran di kelas adalah peneliti. Pengamat aktivitas guru pengajar dilakukan oleh salah satu observer, dan pengamat aktivitas siswa dilakukan oleh peneliti bersama dengan observer peneliti yaitu Guru bidang studi pendidikan matematika yang biasa mengajar dikelas tersebut. Kedua kelas diberikan materi yang sama yaitu materi pokok bangun ruang sisi datar. Kedua kelas yaitu kelas eksperimen dan kelas kontrol diberikan bahan ajar yang sama. Perbedaan yang diberikan pada kedua kelas ini yaitu model pembelajaran yang diberikan dimana untuk kelas eksperimen diajar dengan menggunakan model pembelajaran TSTS, sedangkan pada kelas kontrol diajar dengan menggunkan model pembelajaran konvensional.

Rata-rata persentase pelaksanaan pembelajaran dengan model pembelajaran kooperatif tipe TSTS dari pertemuan pertama sampai pertemuan kelima yakni $81 \%$. Kekurangan-kekurangan yang dilakukan guru pada proses pembelajaran di kelas eksperimen, disebabkan karena guru masih berusaha menyesuaikan diri dengan kondisi pembelajaran yang baru dan karakteristik siswa yang beragam. Oleh karena itu, untuk memperbaikinya peneliti lebih menyesuaikan langkahlangkah pembelajaran dengan waktu yang dibutuhkan dan lebih mencoba mengenal dan memahami karakter siswa yang beragam.

Berdasarkan hasil observasi aktivitas siswa dalam pelaksanaan pembelajaran matematika menggunakan model pembelajaran kooperatif tipe TSTS pada materi bangun ruang sisi datar, pada pertemuan pertama ketercapaian seluruh aspek yang diamati adalah $68,18 \%$. Pada pertemuan kedua sudah mulai mengalami peningkatan, yakni 76,18. Hal ini disebabkan karena siswa mulai menyadari bahwa ada model pembelajaran baru yang digunkan di kelas, sehingga mereka masi penasaran dengan prosesnya. Siswa juga sudah mulai mengerti dengan temanteman kelompok yang diberikan.

Pertemuan ketiga sampai dengan pertemuan keenam memperlihatkan peningkatan ketercapaian aspek yang diamati yakni berturut-turut $81,81 \%$, $87,5 \%$, 90,9\%. Pada pertemuan ketigasampai pada pertemuan kelima, siswa sudah mulai terbiasa dengan LKPD dengan teman kelompoknya serta mau saling berkomunikasi untuk menyelesaikan LKPD yang diberikan. Akan tetapi, mereka masih mengalami kesulitan dalam menemukan penyelesaian masalah sendiri dalam LKPD, sehingga bimbingan dan motivasi dari guru masih sangat diperlukan. Secara umum, ketercapaian keseluruhan aspek yang diamati mengalami peningkatan jika dibandingkan dengan pelaksanaan pada pertemuan pertama. Secara keseluruhan rata-rata presentase keaktifan siswa dari pertemuan pertama sampai pertemuan kelima yakni mencapai $80,91 \%$, yang berarti siswa sudah tergolong aktif. 
Deskripsi hasil tes kemampuan komunikasi matematis siswa pada kelas eksperimen dan kelas kontrol, mula-mula dimulai dari tahap persiapan instrumen tes. Soal-soal Posttest yang digunakan terlebih dahulu diujicobakan dengan tujuan untuk mengetahui validitas dan reliabilitasnya. Tes tersebut diujicobakan kepada 39 siswa di kelas VIII SMP Negeri 12 Kendari pada tanggal 5 Mei 2018. Selanjutnya diadakan pengolahan data untuk mengetahui soal yang memenuhi kriteria valid dan reliabel. Dari hasil perhitungan menunjukkan bahwa dari keenam soal semuanya valid, dan keenam soal tersebut semuanyan akan digunakan dalam instrumen posttest. Reliabilitas tes berada pada kategori sedang dengan $r_{11}$ adalah 0,56.

Berdasarkan hasil analisis deskriptif dari data yang diperoleh melalui tes kemampuan komunikasi matematis siswa yang di ujikan pada kelas eksperimen diperoleh rata-rata 78,29 lebih tinggi dari nilai rata-rata yang diperoleh siswa pada kelas kontrol yaitu 73,68. Hal ini menunjukkan bahwa ada pengaruh penerapan model pembelajaran kooperatif tipe TSTS terhadap kemampuan komunikasi matematis siswa pada materi bangun ruang sisi datar.

Dari segi keragaman data (varians), kelas eksperimen memiliki varians data 57,27 sedangkan kelas kontrol memiliki varians 70,18. Nilai varians tersebut menunjukkan data hasil posttest kelas kontrol lebih beragam daripada kelas eksperimen. Median (nilai tengah) dari kelas eksperimen adalah 80 sedangkan median kelas kontrol yaitu 75 . Nilai yang paling sering muncul (modus) dari hasil posttest kelas eksperimen adalah 80,00sedangkan pada kelas kontrol adalah 75,00 . sementara untuk nilai minimum pada kelas eksperimen yaitu 60 sedangkan pada kelas kontrol yaitu 55, namun nilai maksimum dari kedua kelas tersebut sama yaitu 90 .

Berdasarkan hasil uji hipotesis atau uji perbedaan dua rata-rata dengan bantuan SPSS digunakan uji independent sample $t$ - test diperoleh, nilai $\frac{1}{2}$ Sig. $(2-$ tailed $)=$ 0,01 , dalam hal ini nilai $\frac{1}{2}$ Sig. $(2-$ tailed $)<$ 0,05 , sehingga keputusannya adalah tolak $\mathrm{H}_{0}$. Kesimpulannya, rata-rata kemampuan komunikasi matematis siswa yang diajar dengan model TSTS lebih tinggi daripada siswa yang diajar dengan model pembelajaran konvensional. Adanya perbedaan kemampuan komunikasi matematis ini terjadi karena adanya pembelajaran dengan menggunakan model TSTS.

Teknik ini digunakan dalam semua mata pelajaran dan untuk semua tingkat usia anak didik. Struktur Dua Tinggal Dua Tamu dapat memberikan kesempatan kepada siswa untuk membagikan informasi dengan kelompok lain (Lie, 2012). Model pembelajaran kooperatif Dua Tinggal Dua Tamu adalah dua orang siswa tinggal di kelompok dan dua orang siswa bertamu ke kelompok lain. Dua orang yang tinggal bertugas memberikan informasi kepada tamu tentang hasil kelompoknya, sedangkan yang bertamu bertugas mencatat hasil diskusi kelompok yang dikunjunginya (Shoimin, 2014: 222), sehingga akan terjadi komunikasi dan menghasilkan satu kesimpulan yang disepakati dari hasil diskusi tersebut. Dengan demikian, siswa lebih terlatih lagi dalam berkomunikasiuntuk menyelesaikan suatu masalah yang diberikan

matematis siswa kelas VIII11 SMP Negeri 4 Kendari yang diajar dengan model pembelajaran TSTS diperoleh nilai ratarata 78,29, minimum 60,00, maksimum

\section{KESIMPULAN DAN SARAN}

Berdasarkan hasil penelitian dan pembahasan, maka peneliti mengemukakan kesimpulan sebagai berikut. (1) Kemampuan komunikasi Perbedaan Kemampuan Komunikasi Matematis Siswa Yang Diajar Dengan Model Pembelajaran Kooperatif Tipe TSTS Dan Yang Diajar Dengan Model Pembelajaran Konvensional Di Kelas VIII SMPN 4 Kendari 
90, median 80, modus 85,00, standar deviasi 7,57 dan varians 57,27, (2) Kemampuan komunikasi matematis siswa kelas VIII8 SMP Negeri 4 Kendari yang diajar dengan model pembelajaran konvensional diperoleh nilai rata-rata 73,68, minimum 55,00, maksimum 90,00, median 75 , modus 75,00 , standar deviasi 8,38 , dan varians 70,17 dan (3) Kemampuan komunikasi matematis siswa yang diajar dengan model pembelajaran kooperatif TSTS lebih tinggi daripada kemampuan komunikasi matematis siswa yang diajar dengan model pembelajaran konvensional.

Dari hasil penelitian ini dapat disarankan beberapa hal yaitu: (1) Kepada guru yang mengajar mata pelajaran matematika dapat menggunakan model pembelajaran kooperatif tipe TSTS

\section{DAFTAR PUSTAKA}

Aqib, Zainal. 2013. Model-Model, Media, Dan Strategi Pembelajaran Kontekstual (Inovatif). Bandung: Yrama Widya.

Arikunto, Suharsimi. 2005. Dasar-Dasar Evaluasi Pendidikan Edisi 2. Jakarta: Bumi Aksara.

Lie, Anita. 2008. Cooperative Learning: Mempraktikkan Cooperative Learning di Ruang-Ruang Kelas. Jakarta: PT Grasindo.

NCTM. (1989). Curriculum and Evaluation Standards for School Mathematics. Reston, VA: NCTM. [Online]. Tersedia: di:http://herdy07.wordpress.com/201 4/07/04/kemampuan-komunikasimatematika. [10 Januari 2018].

Novita, Rita. 2014. Efektifitas Model Pembelajaran Kooperatif Tipe Think Piar Share (TPS) pada materi trigonometri di kelas XI IA1 SMA Negeri 8 Banda Aceh.Jurnal STKIT Bina Bangsa Meulabo, 5 (1) : 128 135. sebagai salah satu alternatif dalam pembelajaran matematika untuk mengoptimalkan kemampuan komunikasimatematis siswa, (2) Hendaknya komunikasi matematis siswa mendapat perhatian khusus dari pihak guru karena setiap materi yang diajarkan harus mengandung unsur pemahaman didalamnya. (3) Bagi peneliti yang ingin menggunakan model pembelajaran kooperatif tipe TSTSsebaiknya menggunakan teknik tertentu dan harus terlebih dahulu menguasai penggunaan model pembelajaran TSTS, agar dapat memanfaatkan waktu dengan baik sehingga pembelajaran dengan menggunakan model pembelajaran kooperatif tipeTSTS dapat dilaksanakan dengan maksimal

Rusman. 2010. Model-Model Pembelajaran, Mengembangkan Profesionalisme Guru. Jakarta: PT Raja Grafindo Persada.

Setyosari, Punaji. 2013. Metode Penelitian dan Pengembangan. Jakarta: Kencana.

Shoimin, Aris. 2014. 68 Model Pembelajaran INOVATIF dalam Kurikulum 2013. Yogjakarta: Arruzz Media.

Suherman, Erman dkk. 2003. Strategi Pembelajaran Matematika Kontemporer. Jurusan Pendidikan Matematika. Bandung: FMIPA UPI.

Sundayana, Rostina. 2016. Statistika Penelitian Penddikan. Bandung: Alfabeta.

Zukarnaen, Rafiq. 2010. Meningkatkan kemampuan pemecahan masalah dan komunikasi matematik pada siswa SMA melalui Pendekatan OpenEnded dengan Pembelajaran Kooperatif Tipe Coop-Coop. 
Disertasi SPs. Bandung: UPI

Bandung. 